\title{
PELATIHAN MAHASISWA FAKULTAS HUKUM UNISKA SEBAGAI TENAGA MEDIATOR DALAM SENGKETA HUKUM BAGI MASYARAKAT TIDAK MAMPU
}

\author{
Rakhmat Nopliardy, Nurul Listiyani, dan Akhmad Munawar \\ Fakultas Hukum, Universitas Islam Kalimantan \\ E-mail: yb7ksi@gmail.com
}

\begin{abstract}
ABSTRAK
Mengingat masih banyaknya masyarakat kurang mampu yang belum mendapatkan persamaan perlakuan di mata hukum, maka kegiatan Pengabdian kepada Masyarakat sangat bermanfaat untuk masyarakat Kalimantan Selatan, khususnya bagi masyarakat tidak mampu yang sedang mengalami permasalahan hukum. Lembaga Konsultasi dan Bantuan Hukum (LKBH) yang berada di pengelolaannya berada di bawah Fakultas Hukum UNISKA telah berdiri sejak tahun 2008. Akan tetapi hingga saat ini belum mampu secara optimal menghasilkan regenerasi yang secara khusus menangani permasalahan hukum lewat jalur mediasi. Mahasiswa Fakultas Hukum Uniska merupakan tenaga potensial yang dapat dilatih untuk menjadi mediator dalam penanganan masalah hukum lewat jalur non litigasi. Solusi yang ditawarkan dari kegiatan Pengabdian Kepada Masyarakat ini dengan cara melakukan sosialisasi secara optimal dan melakukan pelatihan untuk menghasilkan sumber daya yang memiliki kemakhiran dalam melakukan mediasi. Target luaran dalam bentuk publikasi pada Jurnal Al Ikhlas dan rekayasa sosial peningkatan sumber daya manusia yang handal bagi LKBH dalam melakukan pendampingan ataupun advokasi penyelesaian sengketa bagi masyarakat kurang mampu.
\end{abstract}

Kata kunci : Program Pemberdayaan Masyarakat, Mediator, Mahasiswa, Masyarakat Kurang Mampu.

\section{PENDAHULUAN}

Konstitusi menjamin hak setiap warga negara untuk mendapat perlakuan yang sama di mata hukum, termasuk hak mengakses keadilan melalui bantuan hukum bagi masyarakat miskin yang menghadapi masalah hukum. Masyarakat mampu akan mendapatkan keadilan melalui advokat yang dapat mereka sewa, sedangkan masyarakat tidak mampu akan kesulitan menyewa seorang advokat karena ketidakmampuan mereka dari sisi finansial.

Masyarakat tidak mampu harus menghadapi kenyataan bahwa kondisi sosial politik mereka telah menjadikan mereka tidak dapat mengakses bantuan hukum yang mereka butuhkan. Kemiskinan yang berakibat terhadap rendahnya taraf pendidikan dan pengetahuan menjadikan masyarakat tidak sadar akan hak-haknya.

Universitas Islam Kalimantan 
Muhammad Arsyad Al Banjari adalah

Universitas swasta terbesar di

Kalimantan Selatan, yang terdiri atas 21

Prodi dari 10 Fakultas, yakni Fakultas

Ilmu Sosial dan Politik, Fakultas

Keguruan dan Ilmu Pendidikan,

Fakultas Ekonomi, Fakultas Pertanian,

Fakultas Teknik, Fakultas Studi Islam,

Fakultas Kesehatan Masyarakat,

Fakultas Teknologi Informatika,

Fakultas Hukum, dan Program

Pascasarjana.

UNISKA juga memiliki Lembaga

Konsultasi dan Bantuan Hukum

(LKBH) sebagai salah satu unit bisnis yang memberikan kontribusi secara ekonomi terhadap perguruan tinggi, khususnya Fakultas Hukum UNISKA. LKBH UNISKA didirikan pada tanggal 28 Agustus 2003 berdasarkan Akta Notaris Nomor 65. LKBH merupakan sebuah Lembaga yang berada di bawah universitas dan pengelolaannya dilakukan oleh Fakultas Hukum UNISKA. Dalam prakteknya LKBH melayani bantuan hukum secara litigasi dan non litigasi, di mana sebagian besar tim LKBH merupakan Dosen dan mahasiswa Fakultas Hukum UNISKA. Akan tetapi karena kurang profesionalnya pengelolaan sumber daya dan kurang tersosialisasinya serta banyaknya Lembaga bantuan hukum yang menjadi kompetitor di Banjarmasin, membuat kontribusi LKBH dari nilai ekonomis kepada universitas masih belum maksimal. Secara internal, LKBH sendiri kurang maksimal melakukan regenerasi kepada mahasiswa agar memiliki kemampuan untuk menyelesaikan permsalahan hukum, terutama memberikan bantuan hukum kepada masyarakat kurang mampu.

Dari analisis situasi yang dipaparkan, maka dapat diinventarisir permasalahan yang dihadapi oleh mitra adalah sebagai berikut:

1. Belum tersosialisasi secara utuh kepada mahasiswa tentang fungsi LKBH dalam membantu masyarakat kurang mampu.

2. Metode pelatihan penangan konflik melalui jalur mediasi (non litigasi) yang masih belum dimiliki oleh mitra.

\section{KHALAYAK SASARAN}

Khalayak sasaran dalam kegiatan pengabdian kepada masyarakat dengan tema "Pelatihan Mahasiswa Fakultas Hukum Uniska Sebagai Tenaga Mediator Dalam Sengketa Hukum Bagi Masyarakat Tidak Mampu" adalah 
mahasiswa Fakultas Hukum Uniska yang telah berada pada semester 3 dan semester 5 dengan jumlah 5 orang (1 kelompok).

Pemilihan khalayak sasaran berdasarkan minat mahasiswa yang didapat dari perekrutan secara langsung pada saat pelaksanaan Pendidikan Kemahiran Hukum yang dilaksanakan rutin setiap tahun, selanjutnya dilaksanakan wawancara untuk melihat secara langsung cara berkomunikasi dan penguasaan dasar penangan konflik dari calon khalayak sasaran.

\section{METODE PELAKSANAAN}

Design yang digunakan dalam kegiatan pengabdian adalah diawali dengan studi pendahuluan / identifikasi masalah mitra. Dengan menggunakan rancangan aksi, diharapkan kegiatan pengabdian ini dapat menghasilkan rekayasa sosial berupa terjadinya peningkatan sumber daya manusia dari mahasiswa fakultas hukum dalam melakukan advokasi/ penanganan perkara non litigasi bagi masyarakat kurang mampu.

Agar dapat berjalan efektif, efisiensi dan relevansi dapat terjamin serta dengan merujuk pada model siklus di atas, maka langkah-langkah kegiatan disusun melalui tahapan-tahapan sebagai berikut :

Tahap 1 : mengidentifikasi permasalahan

Pada tahap ini dilakukan identifikasi permasalahan pada khalayak sasaran, yakni Mahasiswa Fakultas Hukum UNISKA dengan dengan parameter telah berada pada semester 3 dan 5 .

Tahap 2. Mengembangkan pola sosialisasi terhadap kelompok yang telah ditentukan

diawali dengan sosialisasi, yang bertujuan untuk saling mengenal (dengan tujuan pendekatan), memberikan informasi dan penyamaan persepsi tentang tema pengabdian kepada masyarakat, dengan langkahlangkah sebagai berikut :

a. Melakukan pre test

b. melakukan sosialisasi pada kelompok sasaran;

c. materi umum, diberikan untuk meningkatkan pengetahuan dari keompok mahasiswa tentang penanganan sengketa melalui proses mediasi;

\section{Tahap 3. Pelatihan}

Secara umum pelatihan ini menggunakan cara belajar orang dewasa (Andragogy), dengan metode yaitu: 
- Presentasi/Ceramah: Menggunakan bahan tayang (power point) yang menarik dan gampang dipahami;

- Diskusi/Tanya Jawab: Peserta dan Pengajar berinteraksi secara setara mendiskusikan hal-hal yang menjadi keingintahuan setiap peserta.

- Simulasi/Praktik: Menggunakan bahan bacaan studi kasus yang dipelajari peserta akan mempraktikkan baik secara individu maupun kelompok;

- Pemutaran Film: Peserta dalam melihat dan mengamati contoh proses mediasi dan Negosiasi serta hal-hal yang relevan dengan proses penyelesaian sengketa/konflik;

- Bahan Bacaan dan Poster: Peserta dapat memperlajari berbagai konsep yang menggambarkan kebutuhan peserta yang berhubunganan dengan proses penyelesaian konflik.

- Permainan (Games): berupa kegiatan kelas yang bertujuan mencairkan suasana (ice breaking), menghindari kejenuhan, membangun dinamika proses belajar dan memiliki hikmah pembelajaran yang relevan dengan tujuan dan output pelatihan.

\section{Tahap 4. Mengevaluasi hasil kegiatan} PkM

Tahapan terakhir kegiatan Pengabdian kepada Masyarakat skema Program Pemberdayaan Masyarakat adalah melakukan evaluasi terhadap hasil kegiatan. Tahapan ini bertujuan untuk menjaga konsistensi kegiatan dengan tujuan/ manfaat yang ingin dicapai yakni berupa peningkatan pemberdayaan mitra.

\section{HASIL}

PELAKSANAAN

\section{KEGIATAN}

Kegiatan pengabdian kepada masyarakat dilaksanakan dengan membagi kegiatan atas beberapa tahap sebagaimana dipaparkan dalam metode pelaksanaan, yakni: tahap persiapan ( meliputi kegiatan identifikasi masalah mitra, menentukan khalayak sasaran, identifikasi masalah khalayak sasaran), sosialisasi proses mediasi, pelatihan, evaluasi hasil kegiatan PkM.

\section{Persiapan}

Pada tahap persiapan tim $\mathrm{PkM}$ memasukkan 3 (tiga) kegiatan utama yang sifatnya berupa koordinasi, inventarisir masalah dan penentuan khalayak sasaran. Koordinasi awal dilakukan antara tim PkM dengan 
LKBH (Lembaga Konsultasi dan Bantuan Hukum (LKBH) Uniska.

Berdasarkan koordinasi

ditemukan permasalahan mitra yang berkaitan dengan minimnya Sumber

Daya Manusia (SDM) anggota

LKBH yang memiliki kemampuan mediasi dalam penanganan perkara, sehingga LKBH fokus menangani masalah hukum lewat jalur litigasi (pengadilan), sedangkan penanganan masalah hukum lewat jalur non litigasi ditangani lebih kearah pendampingan hukum.

Berikut daftar penanganan perkara yang dilakukan oleh LKBH pada tahun 2019 dan 2020:

Tahun 2016

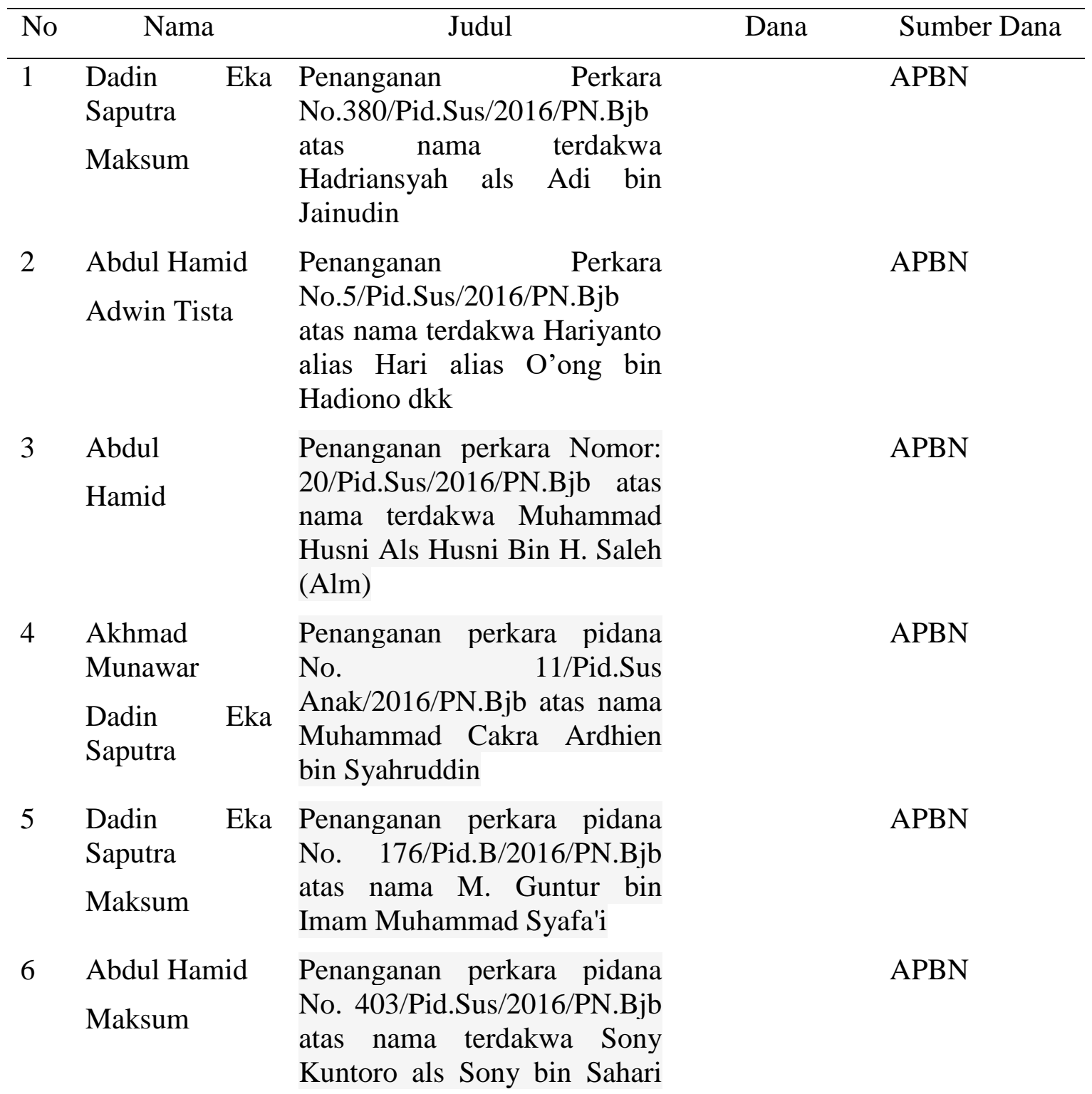


Setyo (Alm)

7 Abdul Hamid Pendampingan perkara

APBN

Akhmad

Munawar 264/Pid.Sus/2016/PN.Bjb atas nama terdakwa Jumbriansyah Als. Jumbri Bin H. Fathani

8 Abdul Hamid

Pendampingan perkara No.

APBN

Maksum

117/Pid.Sus/2016/PN.Bjb atas nama terdakwa Tulus Tiarsih als Thiar Binti Rakhmat

9 Abdul Hamid

Pendampingan perkara No.

APBN

Akhmad

15/Pid.Sus/2016/PN.Bjb atas

Munawar

nama terdakwa Ahmad alias

Haris alias Ari Bin Alan

Tahun 2018

\begin{tabular}{|c|c|c|c|}
\hline 1 & $\begin{array}{l}\text { Dadin Eka } \\
\text { Saputra } \\
\text { Maksum }\end{array}$ & $\begin{array}{l}\text { Pendampingan perkara No. } \\
\text { 266/Pid.Sus/2016/PN.Bjb atas } \\
\text { nama terdakwa M. Joko } \\
\text { Fajriannoor alias Joko bin } \\
\text { Suriadi, dkk }\end{array}$ & APBN \\
\hline 2 & $\begin{array}{l}\text { Akhmad } \\
\text { Munawar } \\
\text { Maksum }\end{array}$ & $\begin{array}{l}\text { Pendampingan perkara No. } \\
\text { 365/Pid.Sus/2016/PN.Bjb atas } \\
\text { nama terdakwa Nova } \\
\text { Emmgiat Prasetia als Nova } \\
\text { bin Nikodemus }\end{array}$ & APBN \\
\hline 3 & $\begin{array}{l}\text { Adwin Tista } \\
\text { Akhmad } \\
\text { Munawar }\end{array}$ & $\begin{array}{l}\text { Pendampingan perkara No. } \\
\text { 376/Pid.Sus/2016/PN.Bjb atas } \\
\text { nama terdakwa Musmuliyadi } \\
\text { alias Utuh bin Anang } \\
\text { Rahmani }\end{array}$ & APBN \\
\hline 4 & $\begin{array}{l}\text { Abdul Hamid } \\
\text { Adwin Tista }\end{array}$ & 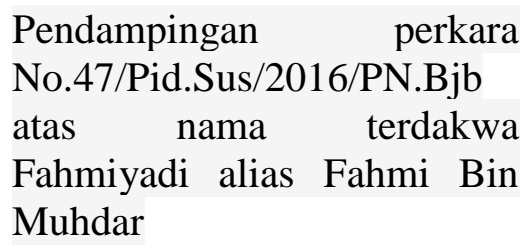 & APBN \\
\hline 5 & $\begin{array}{l}\text { Akhmad } \\
\text { Munawar } \\
\text { Iwan Riswandie }\end{array}$ & $\begin{array}{l}\text { Pendampingan perkara } \\
\text { Nomor: } \\
\text { 134/Pid.Sus/2016/PN.Bjb. } \\
\text { atas nama terdakwa Maisunah } \\
\text { binti Muhidin (Alm) }\end{array}$ & APBN \\
\hline 6 & $\begin{array}{l}\text { Abdul Hamid } \\
\text { Akhmad }\end{array}$ & $\begin{array}{l}\text { Pendampingan perkara } \\
\text { Nomor: } \\
\text { 254/Pid.Sus/2016/PN.Bjb atas }\end{array}$ & APBN \\
\hline
\end{tabular}




\begin{tabular}{ll}
\hline Munawar & $\begin{array}{l}\text { nama terdakwa Bayu Fitriadi } \\
\text { bin Sri Gunawan }\end{array}$ \\
\hline
\end{tabular}

Tahun 2019

\begin{tabular}{|c|c|c|c|}
\hline 1 & $\begin{array}{l}\text { Abdul Hamid } \\
\text { Akhmad } \\
\text { Munawar }\end{array}$ & 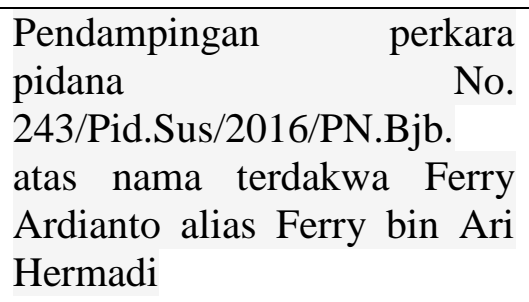 & APBN \\
\hline 2 & $\begin{array}{l}\text { Abdul Hamid } \\
\text { Akhmad } \\
\text { Munawar }\end{array}$ & $\begin{array}{l}\text { Pendampingan perkara } \\
\text { pidana } \\
\text { 377/Pid.Sus/2016/PN.Bjb } \\
\text { atas nama Muhammad } \\
\text { Rasyid alias Onet bin } \\
\text { Muhammad Yunus, dkk }\end{array}$ & APBN \\
\hline 3 & $\begin{array}{l}\text { Abdul Hamid } \\
\text { Maksum }\end{array}$ & $\begin{array}{l}\text { Pendampingan } \mathrm{LKBH} \\
\text { pembuatan BAP atas nama } \\
\text { Mukram Als Utam }\end{array}$ & $\begin{array}{l}\text { Lainnya dalam } \\
\text { Negeri }\end{array}$ \\
\hline
\end{tabular}

\begin{tabular}{lcr}
\multicolumn{1}{c}{ Dari } & data buku & register \\
penanganan & perkara di & LKBH \\
UNISKA & tergambar & bahwa \\
penanganan & perkara yang dilakukan \\
oleh LKBH adalah penangan dalam
\end{tabular}

bentuk litigasi, yakni pendampingan penyelesaian perkara lewat pengadilan, sedangkan penanganan lewat jalur non litigasi masih sangat kurang. Padahal penyelesaian perkara melalui jalur mediasi memiliki banyak kelebihan bagi pihak-pihak yang berperkara diantaranya:
1) Tidak memerlukan waktu terlalu lama untuk penyelesaian




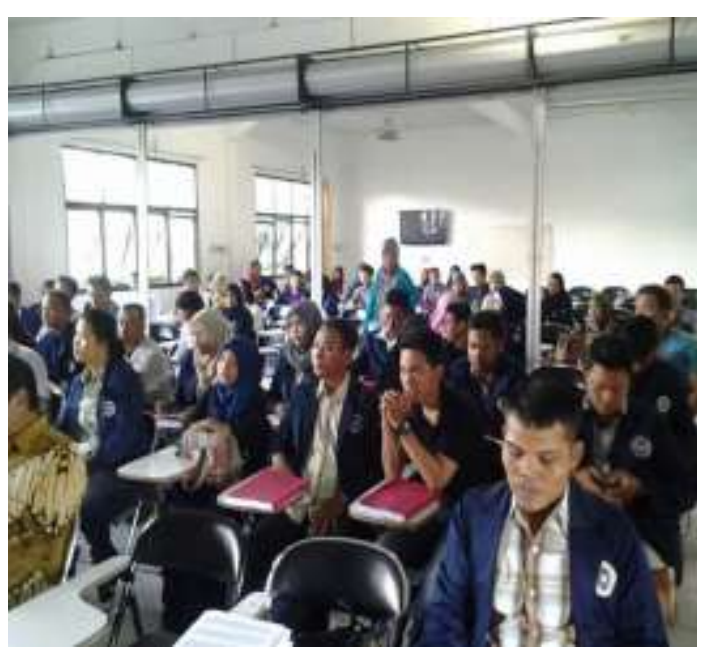

Gambar 2. Pelatihan kemahiran hukum dan sosialisasi mediasi ( hari 1)

Pada tahapan ini dilakukan sosialisasi system kerja LKBH oleh pengurus LKBH dan disisipkan sosialisasi penangangan perkara lewat jalur mediasi oleh tim PkM, dimana salah satu anggota tim yang memberikan materi, Dr. Nurul Listiyani, M.H., merupakan mediator lingkungan hidup dan sumber daya alam tersertifikasi Mahkamah Agung.

\section{Pelatihan}

Sebagaimana jadwal pelatihan, hari pertama (22 Januari 2020) dilakukan pelatihan kemahiran hukum yang dilakukan oleh LKBH yang materinya berkaitan dengan pengenalan LKBH dan penanganan perkara secara umum, sedangkan tim pengabdi melakukan sosialisasi proses mediasi dan kewenangan seorang mediator.

Hari kedua (23 Januari 2020) dilaksanakan pelatihan secara intensif, dimana jumlah peserta hari pertama yang berjumlah 63 orang dikerucutkan menjadi 20 orang dengan melihat pada minta peserta. Acara dimulai pada pukul 09.00 hingga pukul 16.00 wita, bertempat di ruang kuliah Fakultas Hukum Uniska.

Metode pelaksanaan pelatihan mediator dibagi menjadi 3 sesi, yakni sesi penyampaian materi yang disampaikan oleh 2 (dua) orang narasumber, yakni Dr Nurul Listiyani, S.H., M.H., anggota tim sekaligus Mediator tersertifikasi, dan Dr. Masdari Tasmin, S.H., M.H., Praktisi/ advocad senior yang sudah sangat berpengalaman dalam menangani perkara lewat jalur non litigasi.

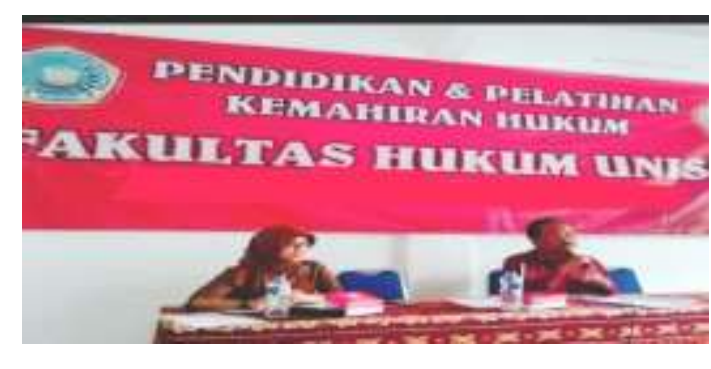

Gambar 4. Penyampaian materi oleh narasumber 
pada pemahaman profesi mediator

Kedua orang narasumber dan kode etik yang harus dipegang menyampaikan materi yang berbeda teguh oleh seorang mediator. akan tetapi memilki korelasi erat dalam peningkatan sumber daya Sedangkan narasumber kedua lebih fokus pada materi penanganan mediator, dimana narasumber konflik dan pembekalan mediator. pertama lebih menekankan materi

Berikut materi yang disampaikan oleh narasumber 1 (Dr. Nurul Listiyani, S.H., M.H.):

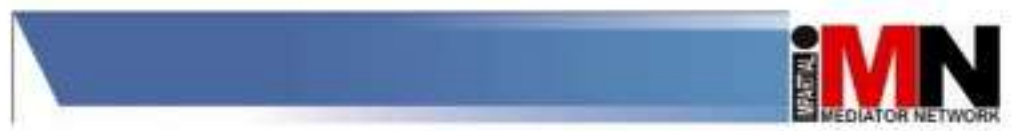

KODE ETIK MEDLATOR

Kode Etik Mediator adalah pokok-pokok pengaturan tentang nilai-nilai atau normanorma yang dijadikan pedoman untuk bertingkah laku dalam rangka kesesuaian standar dalam memberikan pelayanan profesí yaitu Mediasi oleh Mediator-Mediator guna terjaminnya keberlangsungan lembaga profesi dan anggota profesinya.

Profesi yang dimaksud disini adalah profesi mediator sebagai pekerjaan yang dijalankan secara berkeahlian berdasarkan penguasaan ilum tententu yang diperoleh dengan cara dipelajari dan pengajaran tertentu dalam suatu lembaga pendidikan yang terorganisasi secara formal, sehingga mampu menawarkan'memberikan pelayanan jasa kepada masyarakat.

Ketentuan tentang lembaga pendidikan atau pelatihan diatur dalam Peraturan Malskamah Agung (Perma) Nomor 1 tahun 2008 tentang Prosedur Mediasi di Pengadilan Perma ini mengatur tentang hukum acara pelaksanaan medaasi di Pengadilan dan juga mediasi di luar Pengadilan. Pendidikan juga mengacu pada standar-standar lain baik yang bersifat wajb (mandatory) maupun yang bersifat sukarela (voluntary) yang berlaku secara nasional dan global.

\section{BABI \\ KETENTUAN UMUM \\ Pasal 1}

Dalam Kode etik ini yang dimaksud dengan :

1. Mediasi adalah proses penyelesaian sengketa atan konflik yang melibatkan pihak ketiga yang imparsial yaitu Mediator yang membantu Para Pibak yang sedang bersengketa untuk mencapai suatu penyelesaian dalam bentuk suatu kesepakatan secara sukarela terhadap sebagian ataupun selumuh permasalahan yang dipersengketakan.

2. Para Pihak adalah dua atau lebih subyek hnkum atau kuasanya yang bersengketa dalam Magiasi.

3. Mediator adalah seseorang yang Imparsial dalam mediasi dan bertugas membantu dan mendorong Para Pihak yang bersengketa untuk:

1) Berkoumuikasi dan bekerjasama untuk mencapai stiatu penyelesaian dengan itikad baik: 
2) Mengidentifikasi dan menyampaikan permasalahan, kepentingan dan barapan dati satu pihak ke pihak lainnya;

3) Menciptakan, mengembangkan dan mempertimbangkan berbagai bentuk altematif penyelesaian;

4) Mengkaji berbagai kemungkinan resiko dan implikasinya; dan

5) Menyelesaikan persengketann secara sukarela.

4. Katidakberpihakan atau Imparsial adalah bersikap dan tidak menunjukkan sikap memihak terhadap pihak tertentu, terhadap kepentingan pihak tertentu, dan terhadap altematif penyelesaian dari pihak tertentu.

5. Benturan Kepentingan adalah segala bentuk kepentingan yang mempengaruhi Mediator sehingga ia tidak dapat menjalankan Mediasi secara objektif dan Independen.

6. Kesepakatan untuk Mediasi adalah kesepakatan tertulis yang mengikat Para Pihak dan Mediator yang ditandatangani sebehum mediasi dimulai, memuat ketentuan-ketentuan Mediasi yang harus ditaati sebelum, selama dan sesudah proses Mediasi.

Pasal 2

Mediator memiliki tanggung jawab terhadap para pihak uyang dibantu dan terhadap profesinya.

Pasal 3

1. Mediator wajib memelihara dan mempertahankan ketidakberpihakannya, baik dalam wujud kata, sikap dan tingkah laku terhadap para pihak yang terlibat sengketa.

2. Mediator dilarang mempengaruhi atau mengarahkan para pihak untuk menghasilkan syarat - syarat atau klausula - klausula penyelesaian sebuah sengketa yang dapat memberikan keuntungan pribadi bagi mediator.

3. Dalam menjalankan fingsinya, mediator harus beritikad baik, tidak berpihak dan tidak menpunyai kepentingan pribadi serta tidak mengorbankan kepentingan para pihak.

BAB II

KEWAIBBAN MEDIATOR

Pasal 5 
1. Mediator wajib menyelenggarakan proses mediasi sesuai dengan prinsip penentuan diri sendiri oleh para pihak.

2. Mediator wajib memberitahu para pilak pada pertemuan lengkap pertama balwa semua bentuk penyelesaian atau keputusan diambil dalam proses mediasi memerlukan persetujuan para pihak.

3. Mediator wajib menjelaskan kepada para pihak pada pertemuan lengkap pertama tentang pengertian dan prosedur mediasi pengertian kaukus dalam proses mediasi serta peran mediator.

4. Mediator wajib menghormati hak para pihak, antara lain, hak untuk konsultasi dengan penasehat hukumnya atau para ahli dan hak untuk keluar dari proses mediasi.

5. Mediator wajib menghindari penggunaan ancaman, tekanan, atau intimidasi dan paksaan terhadap salah satu atau kedua belah pihak untuk membuat suatu keputusan.

6. Mediator wajib menjaga kerahasiaan informasi yang terungkap di dalam proses mediasi

7. Mediator wajib memusnahkan catatan-catatan dalam proses mediasi, setelah berakhirnya proses mediasi.

\section{Pasal 6}

Mediator wajib memelihara kerahasiaan, baik dalam bentuk perkatain maupun catatan yang terungkap dalam proses mediasi

\section{Pasal 7}

1. Seseorang dilarang untuk menjadi mediator dalam sebuah kasus sengketa yang diketahui bahwa keterlibatannya menimbulkan benturan kepentingan.

2. Dalam hal mediator mengetahui adanya benturan kepentingan atau potensi benturan kepentingan, ia wajib menyatakan mundur sebagai mediator dalam sengketa yang akan atau sedang dalam proses mediasi.

3. Seorang mediator yang berprofesi sebagai advokat dan rekan pada firma hukum yang sama dilarang menjadi penasehat hukum salah satu pihak dalam sengketa yang sedang ditangani baik selama maupun sesudah proses mediasi.

\section{Pasal 8}

1. Mediator wajib menyelenggarakan proses mediasi sesuai dengan jadwal yang telah disepakati para pihak.

2. Mediator wajib menyelenggarakan proses mediasi secara berimbang terhadap para pithak 
3. Mediator wajib menunda atau segera mengakhiri proses mediasi bila perilaku salah satu atau para pihak telah menyalahgunakan proses mediasi atau tidak beritikad baik dalam proses mediasi.

4. Mediator dapat melakukan penundaan atau penghentian Mediasi bila diminta oleh satu atau lebih pihak yang bersengketa.

5. Mediator dapat menunda atau menghentikan proses Mediasi dengan Pertimbangan sebagai berikut:

1) Satu atau lebih Pihak yang bersengketa menunda proses sehingga merugikan pihak lainnya;

2) Proses Mediasi merugikan satu atau lebih pihak atau Mediator:

3) Adanya pihak yang menunjukkan sikap tidak beritikad baik;

4) Alasan-alasan lainnya yang mengakibatkan proses mediasi menjadi tidak efektif bila dilanjutkan;atau

5) Metiyangkut bal-hal yang ditentukan oleh Kode Etik Mediator ini.

Pasal 9

Mediator diharapkan untuk senantiasa meningkatkan kemampuan atau keterampilan tentang mediasi melalui pendidikan, pelatihan, seminar dan konferensi.

Pasal 10

1. Kesepakatan yang dicapai dalan setiap pelaksanaan Mediasi dibagi atas dua macam yaitu: (a) kesepakatan antara, yaitu kesepakatan yang dicapai dalam setiap tahapan mediasi yang dituangkan dalam bentuk berita acara Mediasi; (b) kesepatan akhir atau final, yaitu kesepakatan tentang penyelesaian yang mengakhiri sengketa.

2. Kesepakatan akhir bisa diperkuat menjadi akta autentik di hadapan notaris dan atau diperkuat dengan keputusan Pengadilan Negeri jika para pihak menginginkannnya. 
3. Mediator bisa bertindak sebagai pemantau dan evaluator dalam implementasi kesepakatan jika para pihak menyetujuinya. Lamanya pemantauan dan evaluasi paling lama 6 bulan setelah kesepakatan ditandatangani, kecuali para pihak meminta lebih lama dari 6 bulan.

4. Mediator sebagai pemantau atau evaluator implementasi kesepakatan dapat memfasilitasi Para Pihak untuk merumuskan strategi untuk mengantisipasi timbulnya sengketa baru antara Para Pihak. Strategi tersebut bisa berupa rencana kerjasama jangka panjang antara Para Pihak tidak terbatas dengan kesepakatan pokok yang sudah tercapai.

\section{Pasal 11}

1. Mediator yang berhak memperoleh honorarium mediasi dari para pilak, wajib untuk lebih dahulu membuat kesepakatan tertulis dengan para pihak tentang honorarium dimaksud sebelum menjalankan fimgsinya.

2. Mediator dilarang menerima honorarium berdasarkan hasil akhir proses mediasi.

3. Mediator dilarang menerima hadiah atau pemberian dalam bentuk apapun dari salah satu atau para pihak selama proses mediasi berlangsung selain honorarium yang telah disepakati.

\section{BAB IV \\ PENUTUP}

Pasal 16

1. Profesi Mediator adalah profesi yang mulia dan terhormat, menjalankan tugas pekerjaan untuk mendamaikan Para Pihak yang bersengketa;

2. Mediator dalam melakukan tugasnya dapat dibantu oleh Mediator lainnya dan atau ahli profesi lainnya.

3. Setiap Mediator harus menjunjung tinggi Kode Etik Mediator dalam melakukan profesi sebagai Mediator.

Sesi ke 2 (dua) dilaksanakan tanya jawab berkaitan dengan materi pelatihan yang disampaikan. Selanjutnya pada sesi ke 3 (tiga) yang merupakan inti dari kegiatan pelatihan mediator adalah praktik penanganan perkara yang disatukan dengan praktik kemahiran hukum berupa pembuatan surat kuasa dan 
surat gugatan, serta praktik langsung mediasi para pihak yang berperkara.

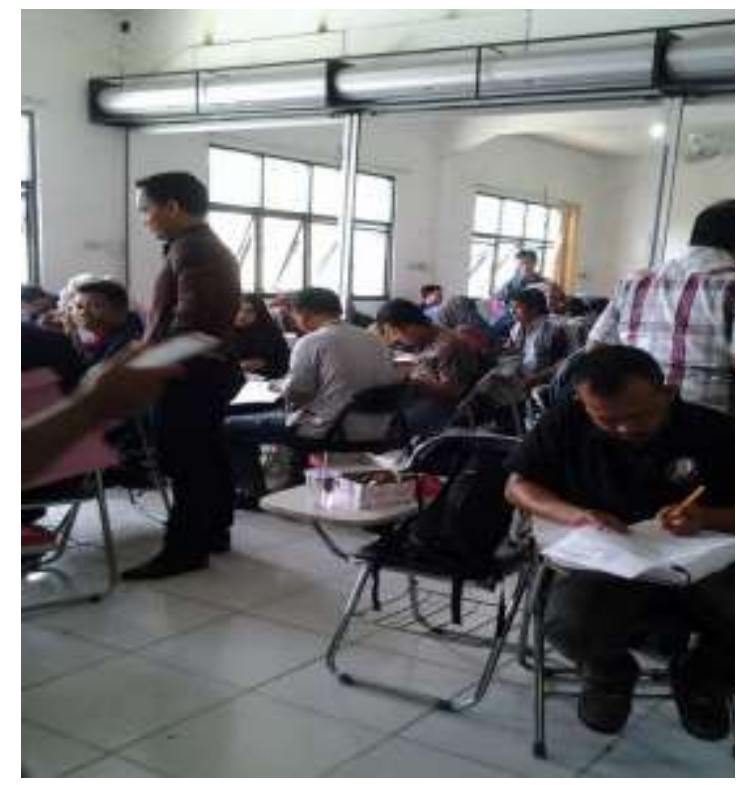

\section{Evaluasi Hasil Kegiatan PkM}

Evaluasi hasil kegiatan sangat penting dilakukan untuk melihat kemampuan peserta dalam memahami materi pelatihan yang disampaikan dan kemudian mampu mengimplementasikannya dalam praktik penanganan perkara yang didampingi secara langsung oleh tim PkM.

Dari hasil evaluasi saat praktik terlihat bahwa kemampuan peserta dalam melaksanakan mediasi masih berada dalam tahap pemula, ini diukur dari indikator yang disusun oleh tim PkM, yakni sebagai berikut:

\begin{tabular}{|c|c|c|c|}
\hline No & Kategori & Indikator & Capaian \\
\hline & Pemula & $\begin{array}{l}\text { - } \text { Memiliki kompetensi Pendidikan } \\
\text { minimal SMA } \\
\text { - Pernah mengikuti pelatihan mediator } \\
\text { - Memiliki kemampuan berkomunikasi } \\
\text { dengan baik } \\
\text { - Memiliki integritas yang tinggi }\end{array}$ & $\begin{array}{l}\checkmark \\
\checkmark\end{array}$ \\
\hline & Mampu & $\begin{array}{l}\text { - Memiliki kompetensi Pendidikan } \\
\text { minimal S1 } \\
\text { - Pernah mengikuti Pendidikan mediator } \\
\text { - Memiliki kemampuan berkomunikasi } \\
\text { dengan baik } \\
\text { - Memiliki integritas yang tinggi } \\
\text { - Mampu menjaga kerahasiaan para pihak } \\
\text { - Mampu bersikap adil terhadap para pihak }\end{array}$ & \\
\hline
\end{tabular}


- Pernah melakukan pendampingan penaganan perkara non litigasi

Mahir - Memiliki kompetensi Pendidikan minimal S1

- Pernah mengikuti Pendidikan mediator yang dilaksanakan oleh Lembaga Mediator yang tersertifikasi oleh Mahkamah Agung.

- Terdaftar sebagai Mediator tersertifikasi pada Mahkamah Agung

- Memiliki kemampuan berkomunikasi dengan baik

- Memiliki integritas yang tinggi

- Mampu menjaga kerahasiaan para pihak

- Mampu bersikap adil terhadap para pihak

- Pernah melakukan pendampingan penaganan perkara litigasi dan non litigasi

\section{KESIMPULAN}

Penanganan konflik melalui proses mediasi masih belum tersosialisasikan dengan baik. Hal ini tergambar dari penanganan konflik yang telah dilakukan oleh LKBH yang cenderung lebih kearah penyelesaian lewat jalur litigasi.

Belum terpenuhinya indikator capaian setelah dilaksanakan pelatihan karena SDM yang masih kurang optimal, padahal banyak sekali keuntungan penyelesaian konflik melalui proses mediasi, diantaranya: Tidak memerlukan waktu terlalu lama untuk penyelesaian, tidak berbelit-belit, biaya dapat diminimalisir, tidak ada pihak yang dikalahkan.

\section{DAFTAR PUSTAKA}

Prasetyo, Teguh, Keadilan Bermartabat Perspektif Teori Hukum (Nusa Media 2015).

Sukinta, Peranan Lembaga Bantuan Hukum Bagi Masyarakat dalam Memperoleh Keadilan (Fakultas Hukum Universitas Diponegoro 1997).

Asfinawati, 'Prolog: Bantuan Hukum Cuma-Cuma dan Komersialisasi' dalam Lembaga Bantuan Hukum Jakarta, Bantuan Hukum Akses Masyarakat Miskin dan Marjinal terhadap Keadilan (LBH Jakarta 2007).

Handayani, Tri Astuti, Pengaturan Bantuan Hukum Dalam Perkara 
Pidana Sebagai Upaya Memenuhi Hak Tersangka Atau Terdakwa Yang Tidak Mampu (Disertasi, Program Doktor Ilmu Hukum Fakultas Hukum Universitas Tujuh Belas Agustus 2015).

Pujiono, 'Bantuan Hukum dalam Perspektif Tanggungjawab Negara' (Seminar Bantuan Hukum dan Akses terhadap Keadilan Bagi Masyarakat Marginal, Semarang, Pebruari 2010).

Listiyani, N. \& Nopliardy, R. (2018).

Peran Serta Pelajar dalam
Penegakan Hak Asasi Manusia atas Lingkungan Hidup yang Baik dan Sehat di SMA Negeri I Bajuin. Jurnal Pengabdian Al Ikhlas Vol. 3 No. 2, 120-129.

Listiyani, N. \& Ambarsari, N. (2019). Sosialisasi tentang Kesadaran Kedudukan Wanita dalam Perkawinan bagi Warga Negara Binaan Wanita di Lembaga Pemasyarakatan Kelas IIA Banjarmasin. Jurnal Pengabdian Al Ikhlas Vol. 5 No. 1, 36-46. 